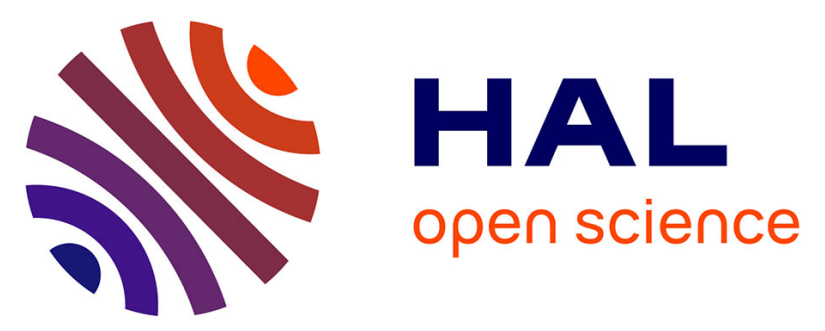

\title{
Alteration and release of aliphatic compounds by the polychaete Nereis virens (Sars) experimentally fed with hydrocarbons
}

Franck Gilbert, Georges Stora, Gaston Desrosiers, Bruno Deflandre, Jean-Claude Bertrand, Jean-Christophe Poggiale, Jean-Pierre Gagne

\section{To cite this version:}

Franck Gilbert, Georges Stora, Gaston Desrosiers, Bruno Deflandre, Jean-Claude Bertrand, et al.. Alteration and release of aliphatic compounds by the polychaete Nereis virens (Sars) experimentally fed with hydrocarbons. Journal of Experimental Marine Biology and Ecology, 2001, vol. 256, pp. 199-213. 10.1016/S0022-0981(00)00317-8 . hal-00763824

\section{HAL Id: hal-00763824 \\ https://hal.science/hal-00763824}

Submitted on 11 Dec 2012

HAL is a multi-disciplinary open access archive for the deposit and dissemination of scientific research documents, whether they are published or not. The documents may come from teaching and research institutions in France or abroad, or from public or private research centers.
L'archive ouverte pluridisciplinaire HAL, est destinée au dépôt et à la diffusion de documents scientifiques de niveau recherche, publiés ou non, émanant des établissements d'enseignement et de recherche français ou étrangers, des laboratoires publics ou privés. 


\title{
Alteration and release of aliphatic compounds by the polychaete Nereis virens (Sars) experimentally fed with hydrocarbons
}

\author{
Franck Gilbert $^{\mathrm{a}, *}$, Georges Stora ${ }^{\mathrm{a}}$, Gaston Desrosiers ${ }^{\mathrm{b}}$, Bruno Deflandre ${ }^{\mathrm{b}}$, \\ Jean-Claude Bertrand ${ }^{\mathrm{a}}$, Jean-Christophe Poggiale ${ }^{\mathrm{a}}$, Jean-Pierre Gagné ${ }^{\mathrm{b}}$ \\ a'Laboratoire d'Océanographie et de Biogéochimie, UMR CNRS 6535, Campus de Luminy, Case 901, \\ F-13288 Marseille Cedex 09, France \\ ${ }^{\mathrm{b}}$ Institut des Sciences de la Mer de Rismouski (ISMER), Université du Québec à Rimouski, \\ 310 Allée des Ursulines, Rimouski, Québec, Canada G5L 3A1
}

\begin{abstract}
In the laboratory, marine worms were fed with a mixture of algae and several aliphatic hydrocarbons for 15 days. After ingestion by the worms, $34.9 \%$ of hydrocarbons are found in the faeces and only $3.1 \%$ accumulated in the gut. The comparison between the initial mixture and the faeces shows that the worm's digestive process lead to changes in the distribution of the $n$-alkane mixture. These changes are different from those only due to physical processes in the experimental conditions. In our experiment, no variation in the distribution of hydrocarbons in faeces with time and no microbial hydrocarbon biodegradation were evidenced. Our results suggest that marine worm feeding can substantially affect the fate of hydrocarbons in the sedimentary marine ecosystem by predominantly stimulating dissolution processes. (C) 2001 Elsevier Science B.V. All rights reserved.
\end{abstract}

Keywords: Digestive process; Hydrocarbons; Marine polychaete; Nereis virens; Solubilization

\section{Introduction}

The activity of benthic organisms modifies the physical and chemical nature of marine sediments (Aller, 1982). In the case of petroleum pollution, if the changes in the chemical environment can affect the sedimentary biota, all the biological processes

*Corresponding author. Tel.: + 33-491-829-104; fax: + 33-491-826-548.

E-mail address: gilbert@mailhost.com.univ-mrs.fr (F. Gilbert). 
included under the term 'bioturbation' play an important role with regard to the fate of hydrocarbon pollutants (Lee and Swartz, 1980).

Previous works dealing with the role of bioturbation in the fate of hydrocarbons have more particularly taken into account their overall weathering related to the biological distribution and transfers of pollutants adsorbed onto the sediment (Gardner et al., 1979; Karickhoff and Morris, 1985; Reynoldson, 1987; Gilbert et al., 1994, 1996; Kure and Forbes, 1997). During the mixing of sediments, bioturbating macrofauna stimulates hydrocarbon desorption for particles (Koerting-Walker and Buck, 1989), and then greatly favours their bioavailability (Mihelcic and Luthy, 1991; Madsen et al., 1997) and resulting bacterial biodegradation (Gordon et al., 1978; Bauer et al., 1988; McElroy et al., 1990). In areas of intensive reworking, where the benthic macrofauna ingests the surface sediment several times a year (Myers, 1977), the digestive activity of macroorganisms, and more especially worms, may represent a non-negligible part of the hydrocarbon handling thus exposed to microbiological transformations (Plante and Jumars, 1992) and to a chemical environment controlled by the digestive chemistry of the organism (Mayer et al., 1997; Gilbert et al., 1998). More especially, passage of hydrocarbons through the worm gut may also result in metabolisation and accumulation (Lee and Singer, 1980; McElroy and Sisson, 1989; Forbes et al., 1996; Fergusson and Chandler, 1998; Sheedy et al., 1998). Moreover, recent works have demonstrated the high hydrocarbon solubilising potential of extracted gut digestive fluids (Mayer et al., 1996; Weston and Mayer, 1998a,b).

The aim of our work was to provide more information on the direct role of macrofauna during its digestive activity with regard to the fate of hydrocarbons in marine sediments. To this end, a laboratory experiment has been carried out with the aim of monitoring the uptake, release and alteration of a mixture of aliphatic hydrocarbons ingested by the marine polychaete Nereis virens. The Nereidae, due to their wide distribution and easy laboratory maintenance and acclimation, are the most suitable genus to test the fate of persistent pollutants in marine animals (Goerke, 1984). In the Saint Lawrence estuary, $N$. virens is one of the most important mudflat species because of its high density (Desrosiers et al., 1994). This worm builds U-shaped burrows in the sediment layer with extension, for adults, up to 30-50 cm below the sediment surface (Goerke, 1976; Kristensen et al., 1985; Miron et al., 1991a). This species inhabits extensive soft substrates in littoral and sub-littoral zones on the coasts of NE North America and NW Europe. Due to urban and industrial activity, this type of environment is highly exposed to the impact of many types of pollutants, particularly hydrocarbons.

\section{Materials and methods}

\subsection{Experimental setup and hydrocarbon tracer preparation}

In November 1996, 20 adult polychaetes Nereis virens (wet weight: 3.16 $\pm 0.29 \mathrm{~g}$; mean \pm S.D.) were randomly collected in the tidal zone of l'Anse à l'Orignal (Bic, Québec, Canada) and placed in four experimental containers $(50 \times 25 \times 5 \mathrm{~cm})$. In the five individual sections of each container, a worm was placed in a transparent horizontal 
glass tube (length: $19 \mathrm{~cm}$; I.D.: $0.7 \mathrm{~cm}$ ) which perfectly substitutes for the natural habitat burrows (Goerke, 1984). Each section was filled with filtered $(2 \mu \mathrm{m})$ seawater which was kept aerated. During the experiment, the room temperature was maintained at $15^{\circ} \mathrm{C}$ and a 12-h light/dark cycle was applied. Before starting the experiment, worms were acclimated to the experimental conditions during 7 days. For the same period, the animals were not fed in order to clear their gut. Later, the different manipulations (feeding, sampling) were done during the dark period and under a red light (Miron et al., 1991b).

The hydrocarbon tracer was made of a mixture of eight $n$-alkanes $\left(n-\mathrm{C}_{14}, n-\mathrm{C}_{15}\right.$, $n-\mathrm{C}_{17}, n-\mathrm{C}_{18}, n-\mathrm{C}_{22}, n-\mathrm{C}_{23}, n-\mathrm{C}_{28}$ and $n-\mathrm{C}_{29}$ ), one isoprenoid alkane (pristane) and one cyclic alkane (androstane) (Fig. 1). Food portions (304 individual portions) were prepared by wrapping a known quantity of tracer $(3.6 \pm 0.2 \mathrm{mg}$; mean \pm S.D.) inside a fresh leaf of the algae Enteromorpha sp. (13.9 $\pm 1.7 \mathrm{mg}$; mean \pm S.D.). The food portions were then preserved frozen to $-20^{\circ} \mathrm{C}$.

\subsection{Polychaete feeding, faeces and gut collection}

At the beginning of the experiment, both experimental tubes and sections were cleaned and the sea water replaced. Then, at the start of the dark period, each worm was individually fed with a food portion which was positioned at the end of the tube towards which the worm's head was pointing. In the following $10 \mathrm{~s}$, the food portion was picked up by the worm. After 2, 4, 8, 12 and $24 \mathrm{~h}$, according to the average time of last faeces extrusion by Nereis virens fed with Enteromorpha sp. (Olivier et al., 1996), the faeces of the worms from each container were sampled in the glass tubes and individual sections, regrouped, weighed and frozen at $-20^{\circ} \mathrm{C}$ before analysis. The sum of faeces

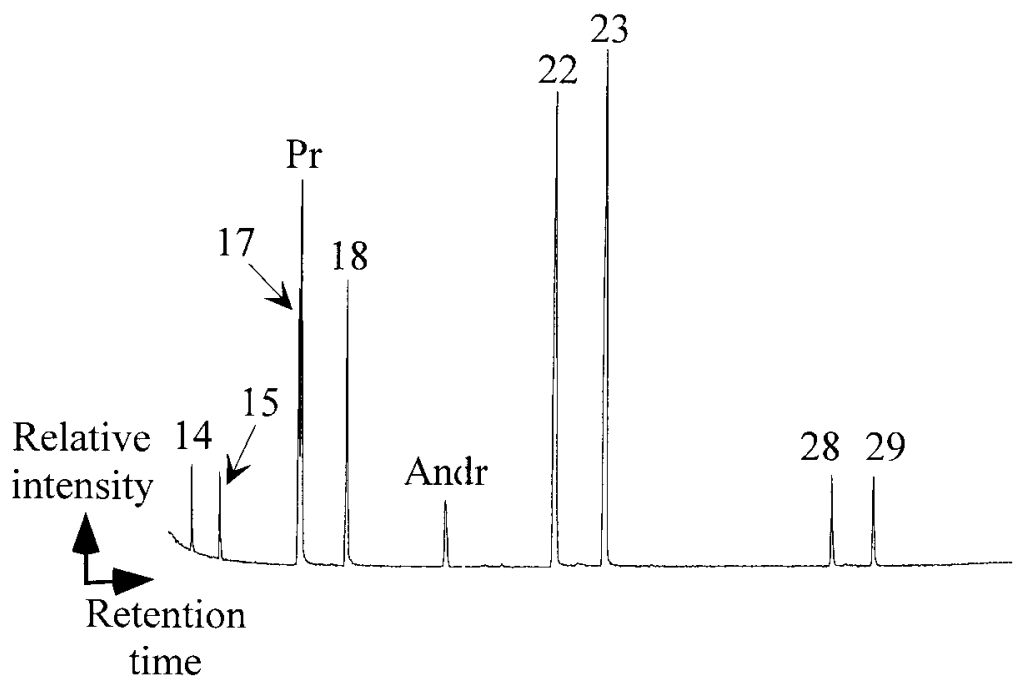

Fig. 1. Chromatogram of the hydrocarbon tracer showing the relative proportions of the different hydrocarbons in the mixture: $n$-alkanes from $n-\mathrm{C}_{14}$ to $n-\mathrm{C}_{29}$, pristane (Pr) and androstane (Andr). 
collected during the first $24 \mathrm{~h}$ sampling is called 'FD1'. After collection of the 24-h faeces, the thin mucous layer with which inhabited tubes were coated was also collected and weighed. The tubes and sections were then cleaned by collecting the food residues, and the sea water was replaced. A new food portion was then given to each worm at a fixed time (08:00 h). During the experiment, worms were fed 15 times (samples: FD1 to FD15).

In an additional container and in absence of worm, four food portions were separately subjected to the same experimental conditions for $24 \mathrm{~h}$ (in order to evidence possible non-worm related changes in tracer composition) and served as controls. The four portions were then collected and separately frozen.

After the 15th day (end of the feeding experiment), the worms were kept for 4 days under the experimental conditions without receiving food to clear their guts (in order to study a possible tracer accumulation in the worms; samples: SD1 to SD4). Then, five worms were sacrificed and their guts were isolated, weighed and frozen before analysis (sample: SD4). The other worms were kept in the experimental conditions without receiving food and were sacrificed for analysis 5, 10, and 15 days later (samples: SD9 to SD19). All these events are compiled in Table 1.

\subsection{Hydrocarbon extraction}

The hydrocarbons were extracted from the crushed materials (faeces and guts)

Table 1

Time set-up of the different phases of the experiment, sequential events and name of the samples ${ }^{\mathrm{a}}$

\begin{tabular}{|c|c|c|c|c|c|}
\hline $\begin{array}{l}\text { Time } \\
\text { (days) }\end{array}$ & $\begin{array}{l}\text { Sample } \\
\text { name }\end{array}$ & $\begin{array}{l}\text { Polychaete } \\
\text { feeding }\end{array}$ & $\begin{array}{l}\text { Faeces } \\
\text { sampling }\end{array}$ & $\begin{array}{l}\text { Mucus } \\
\text { sampling }\end{array}$ & $\begin{array}{l}\text { Gut } \\
\text { sampling }\end{array}$ \\
\hline 1 & FD1 & $X$ & $X$ & $X$ & - \\
\hline 2 & FD2 & $X$ & $X$ & $X$ & - \\
\hline 3 & FD3 & $X$ & $X$ & $X$ & - \\
\hline 4 & FD4 & $X$ & $X$ & $X$ & - \\
\hline 5 & FD5 & $X$ & $X$ & $X$ & - \\
\hline 6 & FD6 & $X$ & $X$ & $X$ & - \\
\hline 7 & FD7 & $X$ & $X$ & $X$ & - \\
\hline 8 & FD8 & $X$ & $X$ & $X$ & - \\
\hline 9 & FD9 & $X$ & $X$ & $X$ & - \\
\hline 10 & FD10 & $X$ & $X$ & $X$ & - \\
\hline 11 & FD11 & $X$ & $X$ & $X$ & - \\
\hline 12 & FD12 & $X$ & $X$ & $X$ & - \\
\hline 13 & FD13 & $X$ & $X$ & $X$ & - \\
\hline 14 & FD14 & $X$ & $X$ & $X$ & - \\
\hline 15 & FD15 & $X$ & $X$ & $X$ & - \\
\hline 16 & SD1 & - & $X$ & $X$ & - \\
\hline 17 & SD2 & - & $X$ & $X$ & - \\
\hline 18 & SD3 & - & $X$ & $X$ & - \\
\hline 19 & SD4 & - & $X$ & $X$ & $X$ \\
\hline 24 & SD9 & - & $X$ & $X$ & $X$ \\
\hline 29 & SD14 & - & $X$ & $X$ & $X$ \\
\hline 34 & SD19 & - & $X$ & $X$ & $X$ \\
\hline
\end{tabular}

\footnotetext{
${ }^{a}$ Feeding phase (FD): from day 1 to day 15 ; starvation phase (SD): from day 16 to day 34.
} 
supplemented with $n$-eicosane as internal standard by maceration in $10 \mathrm{ml}$ of dichloromethane and sonication for $15 \mathrm{~min}$. The mixture was then centrifuged at $7000 \times g$ for 10 min and the supernatant filtered (Whatman GF/C). This extraction procedure was repeated three times for each sample. The three fractions collected were pooled and dichloromethane was removed by evaporation. The dried sample was redissolved in $1 \mathrm{ml}$ hexane and loaded into a pre-conditioned (successive elutions of $10 \mathrm{ml}$ toluene and 10 $\mathrm{ml}$ hexane) mini chromatographic column Alumina N Sep-Pak Plus Cartridge. The aliphatic hydrocarbons were then eluted with $10 \mathrm{ml}$ of hexane, evaporated at room temperature under $\mathrm{N}_{2}$ flow and stored before analysis.

\subsection{Gas chromatography-mass spectrometry (GC-MS)}

GC-MS analyses were carried out on a HP 5890 series II plus gas chromatograph coupled with a HP 5972 mass spectrometer operated at $70 \mathrm{eV}$ with a mass range $\mathrm{m} / \mathrm{z}$ 50-550 and a cycle time of $1.5 \mathrm{~s}$. The gas chromatograph was equipped with a fused-silica capillary column $(30 \mathrm{~m} \times 0.25 \mathrm{~mm}$ I.D.) coated with HP-5MS (film thickness $=0.25 \mu \mathrm{m}$ ), and helium was used as a carrier gas. The samples were injected on-column at $70^{\circ} \mathrm{C}$ and the oven temperature was programmed to $130^{\circ} \mathrm{C}$ at $30^{\circ} \mathrm{C} \mathrm{min}{ }^{-1}$ and then at $3^{\circ} \mathrm{C} \min ^{-1}$ to $310^{\circ} \mathrm{C}$.

\subsection{Data analysis}

Differences between materials were studied using a one-way analysis of variance (ANOVA). Bartlett's test was employed to test for homogeneity of variance. Heteroscedastic data were transformed and then evaluated using ANOVA.

\section{Results}

\subsection{Feeding ethology}

Faeces weights collected in experimental containers with time are given in Fig. 2. The first 2 days (FD1 and FD2), the mean weights of collected faeces (five polychaete individuals in each of the four containers) were $15.7 \pm 5.57$ and $11.9 \pm 3.42 \mathrm{mg}$ (mean \pm S.D.; $n=4$ ), respectively. Then, from the third day (FD3), Enteromorpha sp. leaf fragments appeared in the faecal material resulting in the increase of faeces mean weight that varied from $35.8 \pm 11.45$ to $107.9 \pm 26.61 \mathrm{mg}$ (mean \pm S.D.; $n=4)$ during the feeding experiment (15 days). Then, the worms being on a starvation diet, the mean weight of faeces decreased rapidly to $5.4 \mathrm{mg}$ the 16th day (SD1) to fall to $0.3 \mathrm{mg} 3$ days after (SD4). No more faeces were produced thereafter. ANOVA analysis on faeces data indicated significant differences in weight with time $(* * * P<0.001)$.

Hydrocarbon tracer weight in the faeces showed the same overall pattern with time as for the faeces (Fig. 3). The mean tracer weight was 0.2 and $0.3 \mathrm{mg}$ the first 2 days, respectively. Increasing to a level between 0.9 and $1.5 \mathrm{mg}$ during the feeding experiment, it decreased (to lowest value of $0.06 \mathrm{mg}$ ) when the food was stopped (SD1). Four days later, only $0.03 \mathrm{mg}$ of tracer was measured in the faeces. ANOVA analyses 


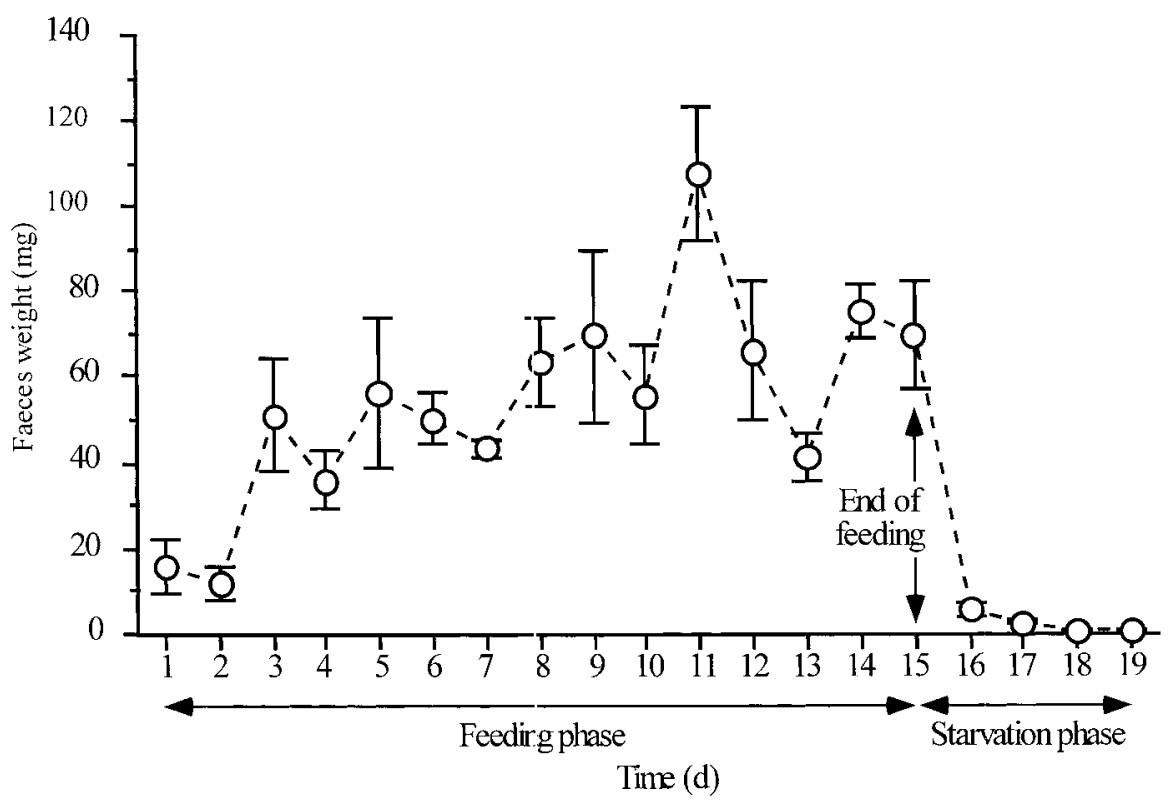

Fig. 2. Faeces weights collected in experimental containers with time during the feeding and starvation phases of the experiment. For the names of the corresponding samples, refer to text and Table 1.

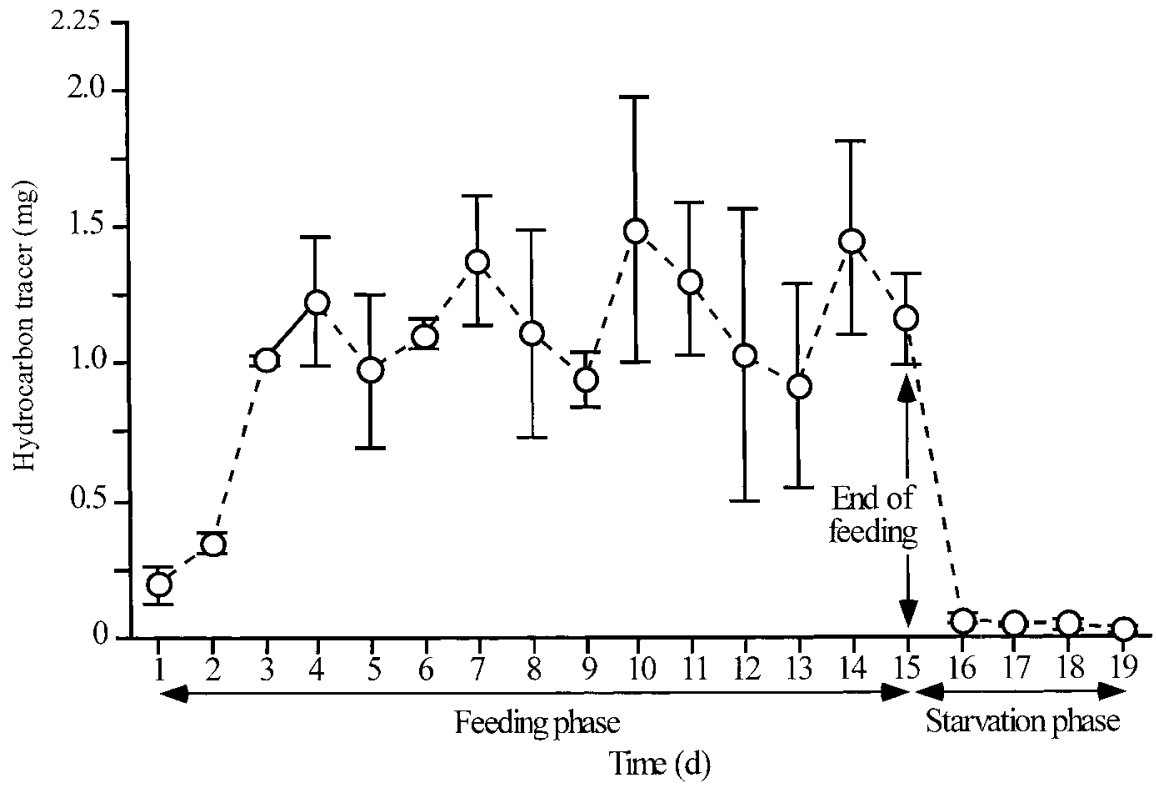

Fig. 3. Hydrocarbon tracer weights extracted from the collected faeces with time during the feeding and starvation phases of the experiment. For the names of the corresponding samples, refer to text and Table 1. 
Table 2

Hydrocarbon tracer weight extracted from the worm gut during the starvation phase ${ }^{\mathrm{a}}$

\begin{tabular}{llllll}
\hline Sample & Polychaete 1 & Polychaete 2 & Polychaete 3 & Polychaete 4 & Polychaete 5 \\
\hline SD4 & 0.03 & 0.30 & 0.08 & 0.11 & 0.06 \\
SD9 & 0.01 & 0.04 & 0.06 & 0.00 & 0.01 \\
SD14 & 0.00 & 0.00 & 0.00 & 0.00 & 0.00 \\
SD19 & 0.00 & 0.00 & 0.00 & 0.00 & 0.00 \\
\hline
\end{tabular}

${ }^{a}$ Samples represent the overall quantities for the five polychaetes of each experimental group. Values are expressed in $\mathrm{mg}$. For the names of the different samples, refer to text and Table 1.

comparing the values showed significant differences among tracer weights as a function of time $(* * * P<0.001)$.

Four days after receiving the last food portions, the analyses indicated slight quantities of tracer in the polychaete guts (SD4) and then a total disappearance after 10 days (Table 2).

Table 3 presents the calculation of mass balance for both total solid material and hydrocarbon tracer. By comparing the total quantities of materials ingested (food) and produced (faeces and mucus) by the worms, we have measured a $25.97 \%$ loss $(-1305.18 \mathrm{mg})$ of solid material during the experiment. At the same time, $93.96 \%$ (996.90 $\mathrm{mg}$ ) of tracer was not recovered in both faeces and guts (no tracer was found in mucus) compared to the ingested quantity.

During the experiment, we have also observed a 25.7, 32.5, 38.5 and 37.6\%, loss in polychaete weight after 19, 24, 29 and 34 days, respectively (Fig. 4).

\subsection{Hydrocarbon tracer}

Fig. 5 presents the changes in hydrocarbon tracer quantity in the different materials (initial tracer, control, faeces and polychaete gut). Results showed that there was a loss of tracer in relation to the initial food portion. Moreover, a higher loss was recorded for the faeces (i.e. $-65.1 \%$ for the overall faeces produced after the last day of feeding period) than for the control $(-26.5 \%)$. This was confirmed by the ANOVA analysis comparing the tracer quantity that indicated three significantly different $(* * * P<0.001)$

Table 3

Mass balances for total solid material and hydrocarbon tracer (values are expressed in $\mathrm{mg}$ )

\begin{tabular}{lll}
\hline Ingested food & \multicolumn{2}{l}{ Solid material produced } \\
\cline { 2 - 3 } & Faeces & Mucus \\
\hline 5025.38 & 3298.71 & 421.49 \\
Ingested tracer & \multicolumn{2}{l}{ Sampled tracer } \\
\cline { 2 - 3 } & In faeces & In guts \\
\hline 1061.04 & 63.44 & 0.70 \\
\hline
\end{tabular}




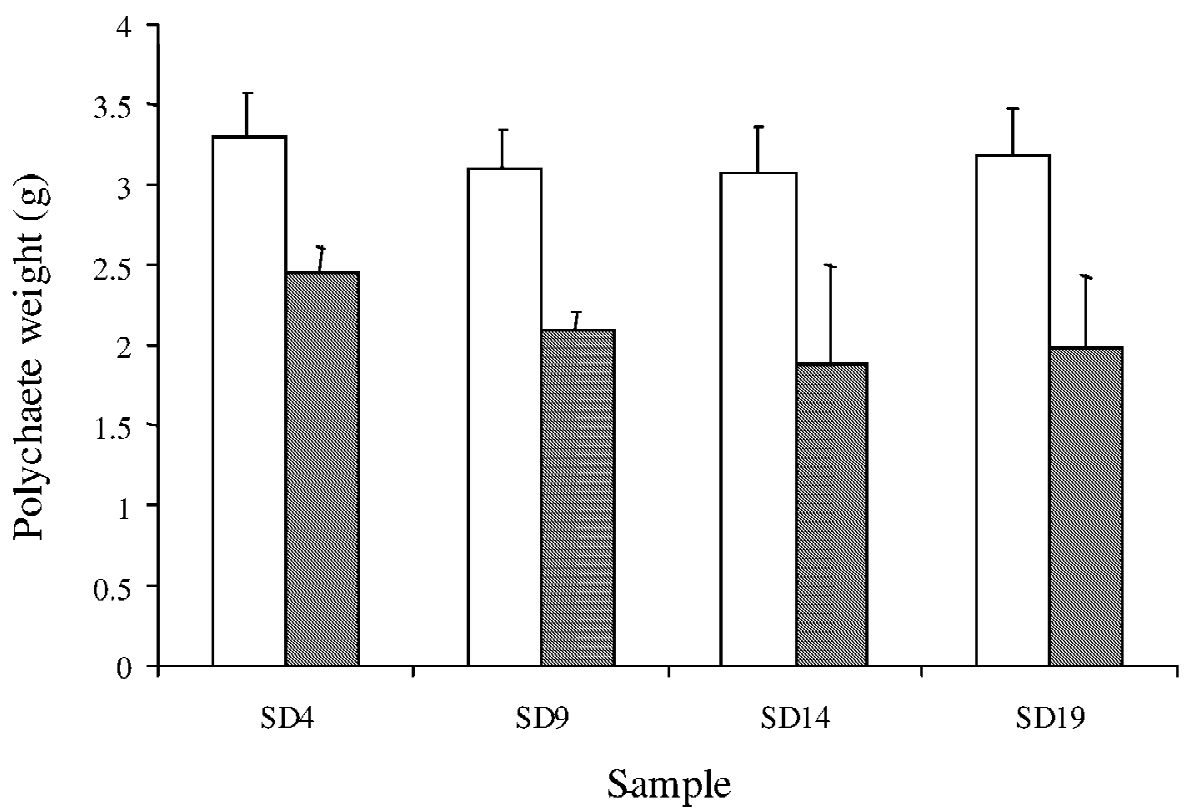

Fig. 4. Polychaete weights (mean \pm S.D. for five individuals) before (open bar) and after the feeding phase (starvation phase; dashed bar) of the experiment. For the names of the different samples, refer to text and Table 1.

groups: Initial Tracer, Control and Faeces. In the same time, the tracer content in the polychaete gut after total clearing represented $3.1 \%$ of the initial tracer content.

Since qualitative tracer analyses of the faeces samples are equivalent throughout the experiment time, only the results for FD3, FD6, FD9 and FD15 are presented to give a readable presentation of the data (Fig. 6 and Table 4).

The recovery percentage of the different hydrocarbon components of the tracer indicated that all the compounds of the initial tracer (food portion) were present in the control and faeces (Fig. 6). It appeared that the distribution of the $n$-alkanes changed with the experimental conditions. The loss was greater for the low molecular weight $n$-alkane (LALK; Steinhauer and Boehm, 1992) than for the heavy molecular weight $n$-alkanes (HALK; from $n-\mathrm{C}_{22}$ to $n-\mathrm{C}_{29}$ ) in the control (Fig. 6, Table 4). On the other hand, the changes in the tracer composition induced by ingestion of the initial tracer by worms were different from the controls. In the faeces, an increased loss of the low molecular weight compounds (n-alkanes from $n-\mathrm{C}_{14}$ to $n-\mathrm{C}_{18}$ and pristane) was apparent, whereas the differences measured for the highest molecular weight $n$-alkanes, excepted for the $n-\mathrm{C}_{29}$ compound, were lower (Fig. 6). This resulted in a global greater decrease of LALK/HALK ratios (Table 4). In the guts, the presence of $n$-alkanes from $n-\mathrm{C}_{22}$ to $n-\mathrm{C}_{29}$ was shown (Tables 4 and 5). Because some compounds were below the detection limit, ratios from gut samples were not used for the ANOVA analysis.

The ANOVA analysis comparing the LALK/HALK ratios indicated a significant 


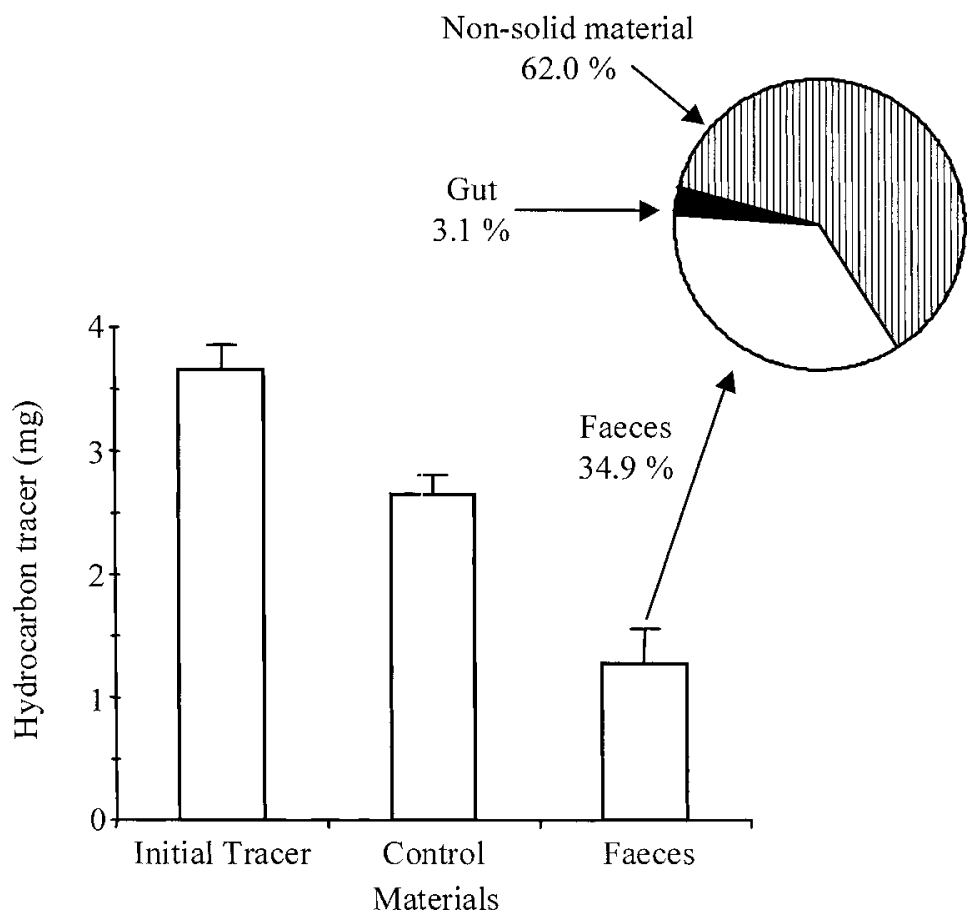

Fig. 5. Quantity of tracer in the different materials and partition of the tracer in faeces, worm guts and in non-solid associated materials. Initial Tracer: food portion; Control: food portion submitted to experimental conditions for $24 \mathrm{~h}$ in absence of worms; Faeces: sum of faeces from FD15 to SD4 samples corresponding to the total clearing of worm guts; Gut: SD4 sample, tracer gut content after total clearing. The non-solid associated material represents the difference between the ingested tracer and solid associated material tracer quantities. Values are mean \pm S.D.; $n=300$ for the Initial Tracer, $n=4$ for the other materials.

difference $(* * * P<0.001)$ between the three types of material (Initial Tracer, Control and Faeces) but no difference between the different faeces samples (FD3, FD6, FD9 and FD15).

Calculated $n-\mathrm{C}_{17} /$ Pr ratios were higher in the Control and faeces samples compared to the Initial Tracer (Table 4). However, the faeces samples presented a slighter increase than the Control. As found with the LALK/HALK ratios, ANOVA analysis comparing the $n-\mathrm{C}_{17} / \mathrm{Pr}$ ratios indicated a significant difference $(* * P<0.01)$ between the three types of material (Initial Tracer, Control and Faeces) but no difference between the different faeces samples.

Calculated SALK/Andr ratios were also higher in the Control and faeces samples compared to the Initial Tracer, except for the FD6 sample (Table 4).

ANOVA analysis indicated no significant difference either between Initial Tracer and FD6, or between Control and FD3, and no difference between FD9 and FD15. On the other hand, between these three groups, the ratios were significantly different $(* * P<$ $0.01)$. 


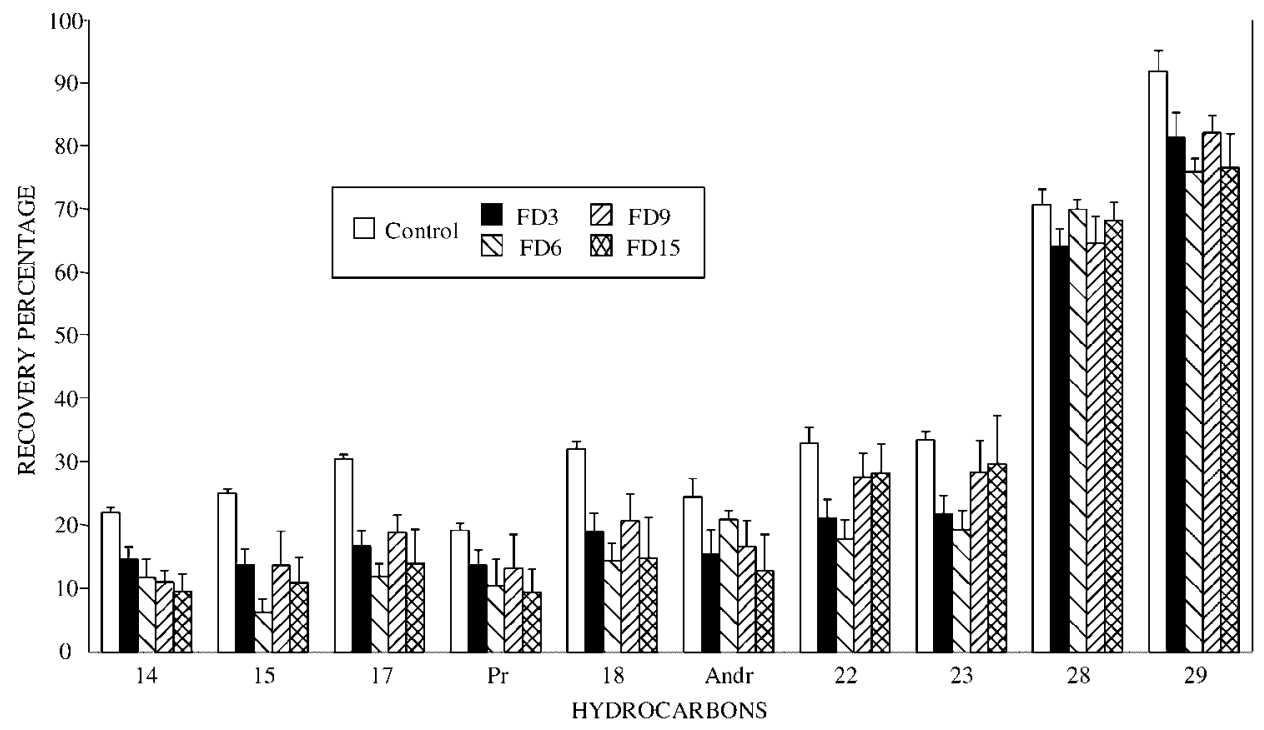

Fig. 6. Recovery percentage (mean \pm S.D.; $n=4$ ) of the various compounds measured in the controls and the faeces samples compared to the initial tracer (food portion) composition. Numbers refer to carbons in $n$-alkanes $\left(n-\mathrm{C}_{14}\right.$ to $\left.n-\mathrm{C}_{29}\right)$; Pr: pristane; Andr: androstane. For the names of the different samples, refer to text and Table 1 .

\section{Discussion}

In this type of laboratory experiment, it is important to choose a good diet procedure to be quite sure that animals take the entire contaminated ration. In 1984, Goerke showed that using oral dosing through the foods occurs presented a very high uptake efficiency. This procedure is particularly useful if the test compounds are highly volatile or have extremely low water-solubility such as polychlorinated biphenyl. For this reason we chose this method for our study on the release of hydrocarbons by the polychaete Nereis virens after transit in the digestive tract.

We can separate this experiment in three steps: FD1-FD2; FD3-FD15, characterised by the presence of algae fragments; and the starvation phase (SD1-SD19). The

Table 4

LALK/HALK, $n-\mathrm{C}_{17} / \mathrm{Pr}$ and $\Sigma$ ALK/Andr ratios of the hydrocarbon $n$-alkane composition calculated for the different samples ${ }^{\mathrm{a}}$

\begin{tabular}{lrrrrrrr}
\hline & Initial tracer & \multicolumn{1}{c}{ Control } & \multicolumn{1}{c}{ FD3 } & \multicolumn{1}{c}{ FD6 } & \multicolumn{1}{c}{ FD9 } & FD15 & SD4 (gut) \\
\hline LALK/HALK & $0.91 \pm 0.02$ & $0.73 \pm 0.02$ & $0.34 \pm 0.03$ & $0.39 \pm 0.03$ & $0.54 \pm 0.05$ & $0.42 \pm 0.04$ & $<0.03$ \\
$n$-C $_{17} /$ Pr & $0.67 \pm 0.01$ & $1.12 \pm 0.03$ & $0.86 \pm 0.04$ & $0.81 \pm 0.04$ & $0.92 \pm 0.03$ & $0.90 \pm 0.04$ & $<1.32$ \\
$\Sigma$ ALK/Andr & $150.13 \pm 7.19$ & $194.63 \pm 3.98$ & $197.71 \pm 4.28$ & $154.31 \pm 7.32$ & $227.35 \pm 24.80$ & $255.48 \pm 2.35$ & $<125.3$ \\
\hline
\end{tabular}

${ }^{a}$ Values are mean \pm S.D. $(n=4)$. LALK: low molecular weight $n$-alkanes $\left(n-\mathrm{C}_{14}, n-\mathrm{C}_{15}, n-\mathrm{C}_{17}, n\right.$-C $\left.\mathrm{C}_{18}\right)$; HALK: heavy molecular weight $n$-alkanes $\left(n-\mathrm{C}_{22}, n-\mathrm{C}_{23}, n-\mathrm{C}_{28}, n-\mathrm{C}_{29}\right) ; \Sigma A L K$ : sum of all the $n$-alkanes $\left(n-\mathrm{C}_{14}\right.$ to $n-\mathrm{C}_{29}$ ); Pr: pristane; Andr: androstane. For the names of the different samples, refer to text and Table 1 . 
Table 5

Recovery percentage of the various compounds from the initial tracer (food portion) in the faeces (FD15) and gut samples (SD4) ${ }^{\text {a }}$

\begin{tabular}{lcc}
\hline Compound & Faeces (FD15) & Gut (SD4) \\
\hline$n-\mathrm{C}_{14}$ & 9.6 & $<0.01$ \\
$n-\mathrm{C}_{15}$ & 11.0 & $<0.01$ \\
$n-\mathrm{C}_{17}$ & 14.0 & $<0.01$ \\
$\mathrm{Pr}$ & 9.5 & $<0.01$ \\
$n-\mathrm{C}_{18}$ & 14.9 & $<0.1$ \\
$\mathrm{Andr}$ & 12.9 & 0.2 \\
$n-\mathrm{C}_{22}$ & 28.4 & 0.2 \\
$n-\mathrm{C}_{23}$ & 29.8 & 0.2 \\
$n-\mathrm{C}_{28}$ & 68.3 & 1.5 \\
$n-\mathrm{C}_{29}$ & 76.6 & 4.4 \\
\hline
\end{tabular}

${ }^{a} n$-alkanes with indication of the number of carbons in molecule $\left(n-\mathrm{C}_{14}\right.$ to $n$ - $\left.\mathrm{C}_{29}\right)$; $\mathrm{Pr}$ : pristane; Andr: androstane. For the compound quantities considered as non-detectable, the detection limit is indicated.

differences in faeces and tracer weights shown by the variance analysis are due to the wide variability observed in the results between these three groups. During the second step, the experimental diet given to the worms induced no significant clearly defined pattern in both faeces and tracers in faeces release during the experiment. Moreover, throughout the feeding phase, the tracer/faeces ratio $(\mathrm{w} / \mathrm{w} ; 0.021 \pm 0.007 \mathrm{mg} / \mathrm{mg}$; mean \pm S.D.; $n=60$ ) was virtually stable. These results indicate that the experimental diet was well supported by the worms and that no food selection occurred with time. Considering the particulate material mass balance, and because the worms lost weight during the course of the experiment, the deficit in excreted/ingested material could be explained by either a storage of food and hydrocarbons that was masked by a larger gross loss of original tissue or the absence of storage into animals. In the latter case, the hydrocarbon tracer loss, that itself represented $76.4 \%$ of the total loss could be largely responsible for this deficit.

While the hydrocarbon loss in the absence of worms (control) may be explained by physical (e.g. dissolution and volatilization) and microbial non-worm related processes, the low quantity of tracer found in the faeces was first thought to be related to a possible accumulation of tracer by sorption of compounds on the gut membrane during transit. However, it appeared that only $3.1 \%$ of the tracer remained in the gut suggesting that $62.0 \%$ of the tracer was rejected by the worm as non-solid material. Because we continuously sampled faeces during the experiment, we can exclude massive loss of tracer from the particulate matter after deposition (Ernst et al., 1977).

In the frame of our work, the possible changes in the tracer composition related to worm digestive activity have also been investigated.

We first observed that the tracer composition in the controls and faeces varied compared to the initial tracer. For the controls, the modifications in the $n$-alkane distribution ( $n-\mathrm{C}_{14}$ to $n-\mathrm{C}_{23}$; Fig. 7$)$ follow the same pattern than the relative recovery percentage of the different compounds reported to their calculated theoretical solubility (Eastcott et al., 1988). Differences in solubility kinetics between alkanes may explain the lack of correlation between our results and theoretical data for $n-\mathrm{C}_{28}$ and $n-\mathrm{C}_{29}$ 


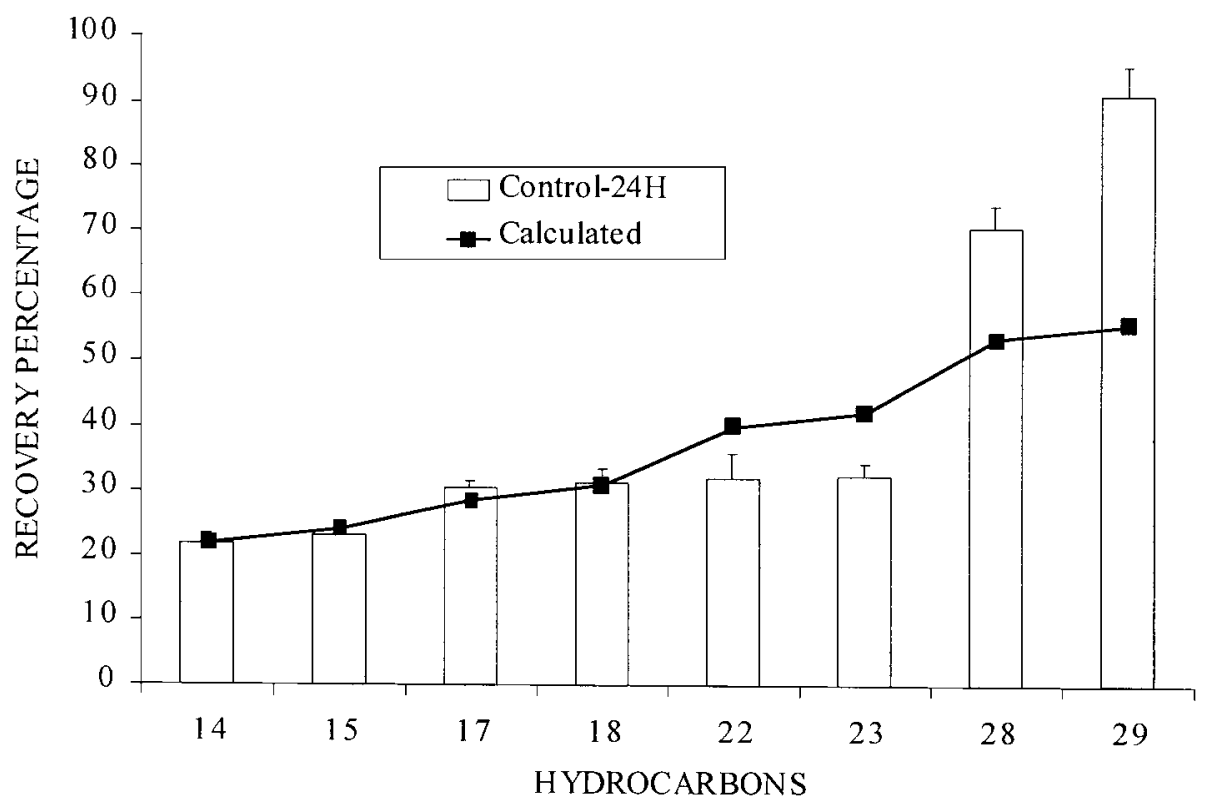

Fig. 7. Recovery percentage of the various $n$-alkanes in the controls compared to the initial tracer (food portion) composition. Both measured (mean \pm S.D.; $n=4)$ and calculated from to their calculated theoretical solubility values are presented. Numbers refer to carbons in $n$-alkanes $\left(n-\mathrm{C}_{14}\right.$ to $n$ - $\left.\mathrm{C}_{29}\right)$.

alkanes (Fig. 7). The lower the solubility of the alkane is, the longer it will take for the theoretical solubility value to be reached. This comparison with the theoretical values suggested that these modifications in the control appeared to be closely related to the physical processes.

For the faeces, it appeared that the worm's digestive process led to different changes than those observed in the controls with a overall decreasing loss of compounds with their increasing molecular weight.

This could not be attributed to a preferential adsorption of the low molecular weight compounds, analysis of worms showing only the presence of $n$-alkanes from $n-\mathrm{C}_{22}$ to $n-\mathrm{C}_{29}$ in the gut (Tables 4 and 5).

Even if the gut transit time was rapid (a day), the alteration in the $n$-alkane tracer composition in the faeces samples may have resulted from biodegradation of compounds in the worm gut and/or biodegradation occurring in the faeces. In order to provide information about the potential microbial attack of the hydrocarbon mixture tracer, two indices comparing the concentrations of $n$-alkanes to other products supposed to be more recalcitrant to alteration were calculated: (i) the $\Sigma$ ALK/Andr ratio, based on the comparison between the sum of $n$-alkanes and androstane (compound of the sterane family that are usually considered as recalcitrant to biodegradation; Peter and Moldowan, 1993; Ledréau et al., 1997) and (ii) the $n-C_{17} /$ Pr ratio, a diagnostic ratio used to study the biodegradation of hydrocarbons (Leahy and Colwell, 1990; Gilbert et al., 1994, 1996). The calculation of the two biodegradation diagnostic ratios invalidated that 
second hypothesis too. For both controls (without worm) and faeces (whatever time), the $\sum$ ALK/Andr and $n-\mathrm{C}_{17} / \operatorname{Pr}$ ratios were higher than the initial one (Table 4), rejecting the admitted evidence of the bacterial degradation of hydrocarbons (Blumer et al., 1973; Atlas, 1981). However, it must emphasized that the faeces samples presented lower $n-\mathrm{C}_{17} / \mathrm{Pr}$ ratios than the controls. This may indicate a weak bacterial process predominantly hidden by another altering process not related to biodegradation.

The very intensive transfer of tracer into the solute phase and the modifications of its composition may be explained by the tearing of the food portion during ingestion followed by the leaching and digestive solubilization of tracer in the worm gut. Recent works (Mayer et al., 1996, 1997; Weston and Mayer, 1998a,b) have demonstrated that the dissolution of organic matter and particularly hydrocarbons was strongly stimulated during gut transit owing to the production of surfactants and others molecules. Even if the presence of surfactants in the digestive fluids is more particularly linked to the presence of sediment in the diet, the production of these powerful solubilizing agents is also high with algae diet (Bock and Mayer, 1999).

In this study, the direct role of the Nereis virens digestive process on the fate of hydrocarbons in the sediments is demonstrated. After ingestion by the worms, the major part of the solid tracer was transferred to the solute phase, only $34.9 \%$ of hydrocarbons being found in the faeces and $3.1 \%$ accumulated in the gut. In addition, the passage through the worm gut altered the composition of the hydrocarbon mixture tracer. The qualitative results and the invariable effect of the digestive transit on the tracer observed with time rule out the role of the internal gut microflora in the tracer transformation and/or its induction by the hydrocarbon diet. Even so, this particular point needs to be clarified by means of specific experiments. The stimulation of both hydrocarbon dissolution and solubilization in the worm gut due to induced surfactant production thus appears to be the major process that can explain both qualitative and quantitative changes of the hydrocarbon tracer.

\section{Acknowledgements}

Authors thank the anonymous reviewers for constructive comments. This work was carried out as part of the G.R.E.C. (Groupe de Recherche en Environnement Côtier, UQAR, Québec, Canada) and the G.D.R. 1123 'HYCAR' (CNRS — Universities Société Elf Aquitaine, France) and was supported by a grant from the Société de Secours des Amis des Sciences to Franck Gilbert and by grants from the Natural Sciences and Engineering Research Council of Canada (CRSNG) to Gaston Desrosiers and JeanPierre Gagné. [SS]

\section{References}

Aller, R.C., 1982. The effects of macrobenthos on chemical properties of marine sediment and overlying water. In: McCall, P.L., Tevesz, M.J.S. (Eds.), Animal-Sediment Relations. Plenum Press, New York, pp. 53-102. 
Atlas, R.M., 1981. Microbial degradation of petroleum hydrocarbons: an environmental perspective. Microbiol. Rev. 45, 180-209.

Bauer, J.E., Kerr, R.P., Bautista, M.F., Decker, C.J., Capone, D.L., 1988. Stimulation of microbial activities on polycyclic aromatic hydrocarbon degradation in marine sediments inhabited by Capitella capitata. Mar. Environ. Res. 25, 63-84.

Bock, M.J., Mayer, L.M., 1999. Digestive plasticity of the marine benthic omnivore Nereis virens. J. Exp. Mar. Biol. Ecol. 240, 77-92.

Blumer, M., Ehrhardt, M., Jones, J.H., 1973. The environmental fate of stranded crude oil. Deep Sea Res. 20, 239-259.

Desrosiers, G., Caron, A., Olivier, M., Miron, G., 1994. Cycle de développement du pluchète (Sars) dans la zone intertidale de l'Estuaire maritime du Saint-Laurent. Oceanol. Acta 17, 683-697.

Eastcott, L., Shiu, W.S., Mackay, D., 1988. Environmentally relevant physical-chemical properties of hydrocarbons: a review of data and development of simple correlations. Oil Chem. Pollut. 4, 191-216.

Ernst, W., Goerke, H., Weber, K., 1977. Fate of ${ }^{14}$ C-labelled di-, tri- and pentochlorbiphenyl in the marine annelid. II. Degradation and faecal elimination. Chemosphere 6, 559-568.

Fergusson, P.L., Chandler, G.T., 1998. A laboratory and field comparison of sediment polycyclic aromatic hydrocarbon accumulation by the cosmopolitan estuarine polychaete Streblospio benedicti (Webster). Mar. Environ. Res. 45, 387-401.

Forbes, V.E., Forbes, L.F., Holmer, M., 1996. Inducible metabolism of fluoranthene by the opportunistic polychete Capitella sp. I. Mar. Ecol. Prog. Ser. 132, 63-70.

Gardner, W.S., Lee, R.F., Tenore, K., Smith, L.W., 1979. Degradation of selected polycyclic aromatic hydrocarbons in coastal sediments: importance of microbes and polychaete worms. Water Air Soil Pollut. 11, 339-347.

Gilbert, F., Rivet, L., Bertrand, J.-C., 1994. The in vitro influence of the burrowing polychaete Nereis diversicolor on the fate of petroleum hydrocarbons in marine sediments. Chemosphere 29, 1-12.

Gilbert, F., Stora, G., Bertrand, J.-C., 1996. In situ bioturbation and hydrocarbon fate in an experimental contaminated Mediterranean coastal ecosystem. Chemosphere 33, 1449-1458.

Gilbert, F., Stora, G., Desrosiers, G., Gagné, J.-P., Deflandre, B., Bertrand, J.-C., 1998. Changes in aliphatic hydrocarbon tracer composition during the marine worm Nereis virens digestive process. Preliminary results. Chemosphere 36, 553-560.

Goerke, H. (Ed.), 1976. Nereidae) Nahrungsaufnahme. Scientific Film E. 1893. Explanation paper. Inst. wiss. Film, Göttingen, p. 11, 4 figs.

Goerke, H., 1984. Testing the fate of xenobiotics in Polychaeta. In: Persoone, G., Jaspers, E., Claus, C. (Eds.). Ecotoxicological Testing For the Marine Environment, Vol. 2. State University Gent and Institute of Marine Scientific Research, Bredene, Belgium, pp. 53-66.

Gordon, Jr. D.C., Dale, J., Keizer, P.D., 1978. Importance of sediment working by the deposit-feeding polychaete Arenicola marina on the weathering rate of sediment-bound oil. J. Fish. Res. Board Can. 35, 591-603.

Karickhoff, S.W., Morris, K.R., 1985. Impact of tubificid oligochaetes on pollutant transport in bottom sediments. Environ. Sci. Technol. 19, 51-56.

Koerting-Walker, C., Buck, J.D., 1989. The effect of bacteria and bioturbation by Clymenella torquata on oil removal from sediment. Water Air Soil Pollut. 43, 413-424.

Kristensen, E., Jensen, M.H., Andersen, T.K., 1985. The impact of polychaete (Nereis virens Sars) burrows on nitrification and nitrate reduction in estuarine sediments. J. Exp. Mar. Biol. Ecol. 85, 75-91.

Kure, L.K., Forbes, T.L., 1997. Impact of bioturbation by Arenicola marina on the fate of particle-bound fluoranthene. Mar. Ecol. Prog. Ser. 156, 157-166.

Leahy, J.G., Colwell, R.R., 1990. Microbial degradation of hydrocarbons in the environment. Microbiol. Rev. 54, 305-315.

Ledréau, Y., Gilbert, F., Doumenq, P., Asia, L., Bertrand, J.-C., Mille, G., 1997. The use of hopanes to track in situ variations in petroleum composition in surface sediments. Chemosphere 34, 1663-1672.

Lee, H., Swartz, R.C., 1980. Biological processes affecting the distribution of pollutants in marine sediments. Part II. Biodeposition and bioturbation. In: Baker, R.A. (Ed.). Contaminants and Sediments, Vol. 2. Ann Arbor Science, Ann Arbor, MI, pp. 555-606. 
Lee, R.F., Singer, S.C., 1980. Detoxifying enzymes in marine polychaetes: increases in activity after exposure to aromatic hydrocarbons. Rapp. P-V Réun. Const. Int. Explor. Mer 179, 29-32.

Madsen, S.D., Forbes, T.L., Forbes, V.E., 1997. Particle mixing by the polychaete Capitella species 1: coupling fate and effect of a particle-bound organic contaminant (fluoranthene) in marine sediment. Mar. Ecol. Prog. Ser. 147, 129-142.

Mayer, L.M., Chen, Z., Findlay, R.H., Fang, J., Sampson, S., Self, R.T.L., Jumars, P.A., Quetel, C., Donard, O.F.X., 1996. Bioavailability of sedimentary contaminants subject to deposit-feeder digestion. Environ. Sci. Technol. 30, 2641-2645.

Mayer, L.M., Schick, L.L., Self, R.F.L., Jumars, P.A., Findlay, R.H., Chen, Z., Sampson, S., 1997. Digestive environments of benthic macroinvertebrate guts: enzymes, surfactants and dissolved organic matter. J. Mar. Res. 55, 785-812.

McElroy, A.E., Sisson, J.D., 1989. Trophic transfer of benzo[a]pyrene metabolites between benthic marine organisms. Mar. Environ. Res. 28, 265-269.

McElroy, A.E., Farrington, J.W., Teal, J.M., 1990. Influence of mode of exposure and the presence of a tubiculous polychaete on the fate of benz $[a]$ anthracene in the benthos. Environ. Sci. Technol. 24, $1648-1655$.

Mihelcic, J.R., Luthy, R.G., 1991. Sorption and microbial degradation of naphthalene in soil-water suspensions under denitrification conditions. Environ. Sci. Technol. 25, 169-177.

Miron, G., Desrosiers, G., Retière, C., Lambert, R., 1991a. Evolution spatio-temporelle du réseau de galeries chez le Polychète Nereis virens (Sars) en relation avec la densité. Can. J. Zool. 69, 39-42.

Miron, G., Desrosiers, G., Retière, C., Lambert, R., 1991b. Dispersion and prospecting behaviour of the polychaete Nereis virens (Sars) as a function of density. J. Exp. Mar. Biol. Ecol. 145, 65-77.

Myers, A., 1977. Sediment processing in a marine subtidal sandy bottom: I. Physical aspects. J. Mar. Res. 35, 609-632.

Olivier, M., Desrosiers, G., Caron, A., Retière, C., 1996. Juvenile growth of the Nereis virens feeding on a range of marine vascular and macroalga plant sources. Mar. Biol. 125, 693-699.

Peter, K.E., Moldowan, J.M., 1993. The Biomarker Guide: Interpreting Molecular Fossils in Petroleum and Ancient Sediments. Prentice-Hall, Englewood Cliffs, NJ.

Plante, C., Jumars, P., 1992. The microbial environment of marine deposit-feeder guts characterized via microelectrodes. Microb. Ecol. 23, 257-277.

Reynoldson, T.F., 1987. Interactions between contaminants and benthic organisms. Hydrobiologia 149, 53-66.

Sheedy, B.R., Mattson, V.R., Cox, J.S., Kosian, P.A., Phipps, G.L., Ankley, G.T., 1998. Bioconcentration of polycyclic aromatic hydrocarbons by the freshwater oligochaete Lumbriculus variegatus. Chemosphere 36, 3061-3070.

Steinhauer, M.S., Boehm, P.D., 1992. The composition and distribution of saturated and aromatic hydrocarbons in nearshore sediments, river sediments, and coastal peat of the Alaskan Beaufort Sea: implications for detecting anthropogenic hydrocarbon inputs. Mar. Environ. Res. 33, 223-253.

Weston, D.P., Mayer, L.M., 1998a. In vitro digestive fluid extraction as a measure of the bioavailability of sediment-associated polycyclic aromatic hydrocarbons: sources of variation and implications for partitioning models. Environ. Toxicol. Chem. 17, 820-829.

Weston, D.P., Mayer, L.M., 1998b. Comparison of in vitro digestive fluid extraction and traditional in vivo approaches as measures of polycyclic aromatic hydrocarbon bioavailibility from sediments. Environ. Toxicol. Chem. 17, 830-840. 